\title{
Gender aspects in skin diseases
}

\author{
W Chen, ${ }^{\dagger, *}$ M Mempel, ${ }^{\dagger}$ C Traidl-Hofmann, ${ }^{\dagger}$ S Al Khusaei, ${ }^{\dagger} \mathrm{J}$ Ring $^{\dagger}$ \\ ${ }^{\dagger}$ Department of Dermatology and Allergy, and ₹Division of Environmental Dermatology and Allergy, Helmholtz Zentrum \\ Munchen/TUM, ZAUM-Center for Allergy and Environment, Technische Universität München, Germany \\ *Correspondence: W Chen. E-mail: wenchieh65.chen@gmail.com
}

\begin{abstract}
Gender differences in medicine have been recognized in anatomy, physiology, as well as in epidemiology and manifestations of various diseases. With respect to skin disorders, males are generally more commonly afflicted with infectious diseases while women are more susceptible to psychosomatic problems, pigmentary disorders, certain hair diseases, and particularly autoimmune as well as allergic diseases. Significantly, more female sex-associated dermatoses can be identified than the male sex-associated dermatoses. Dermatoses in the genital area differ between men and women. Gender differences also exist in the occurrence and prognosis of certain skin malignancies. The mechanisms underlying gender differences in skin diseases remain largely unknown. Differences in the skin structure and physiology, effect of sex hormones, ethnic background, sociocultural behaviour and environmental factors may interact to exert the influences. A better understanding of gender differences in human health and diseases will allow the development of novel concepts for prevention, diagnosis and therapy of skin diseases.
\end{abstract}

\section{Keywords}

oestradiol, gender, skin disease, skin physiology, testosterone

\section{Conflict of interest}

None declared.

\section{Funding sources}

None.

\section{Introduction}

There is growing interest in understanding the sexual dimorphism in medicine over the last decade, ranging from epidemiology, pathophysiology, clinical manifestation, to therapeutic response of various diseases. Gender differences in anatomy, physiology, immunity, genetics as well as geographical and sociocultural backgrounds may all interact contributing to the different disease manifestations between men and women. Sex hormones are the most well known and studied factors exerting the influence on gender development. All naturally existing oestrogens, oestrone, oestradiol (E2) and oestriol, are 18-carbon steroid compounds derived from 19-carbon androgens via irreversible catalysis of cytochrome P-450 19 aromatase. ${ }^{1}$ The differences in sex steroid hormones between men and women depend on the amount of androgens made and the percentage of its conversion. The testes make approximately $7000 \mu \mathrm{g}$ of testosterone ( $\mathrm{T}$ ) per day and convert $0.25 \%$ to $\mathrm{E} 2$, while the ovaries make only $300 \mu \mathrm{g}$ of $\mathrm{T}$ per day but convert half of it to E2. In other words, the androgen amount generated in men is at least 20 times of that in women, but the percentage of androgens converted to $\mathrm{E} 2$ is 200 times higher in women than in men, leading to a 1000 -fold difference in quantity with oestrogen levels at picograms but androgen levels at nanograms.

\section{Gender dimorphism in skin diseases}

Based on clinical observations and epidemiological studies, ${ }^{3-97}$ gender differences have been observed in diversifying spectra of skin diseases. In general, autoimmune dermatoses, allergic diseases, pigmentary disorders and hair diseases show female predominance, while infectious diseases and pre-cancerous/malignant skin diseases occur more often in men (Tables 1 and 2). In addition to pregnancy dermatoses, there are significantly more femalepredominant than male-predominant skin diseases. It seems that the male-predisposed dermatoses mainly occur either in adolescence (e.g. juvenile spring eruption of the ears and acne 
Table 1 Skin diseases with significant female predominance (except female genital or pregnancy diseases)

\begin{tabular}{|c|c|c|}
\hline High (female/male ratio $\geq 9$ ) & Moderate (female/male ratio $5-8$ ) & Low (temale/male ratio 2-4) \\
\hline Autoerythrocyte sensitization syndrome & Lichen sclerosus et atrophicus & Rhematoid arthritis \\
\hline Disseminated discoid lupus erythematosus & $\begin{array}{l}\text { Chronic venous insufficiency/varicose } \\
\text { vein/ulcus cruris venosum }\end{array}$ & Scleroderma \\
\hline Lupus erythematosus (adult) & Morton interdigital neuroma & Antiphospholipid antibody syndrome \\
\hline Sjögren syndrome & Verrucae planae juveniles & Temporal giant cell arteritis \\
\hline Type III hereditary angioedema & Multiple eccrine hidrocystomas & Chronic immune thrombocytopenic purpura \\
\hline Frontal fibrosing alopecia (Kossard) & Loose anagen hair syndrome & Chronic urticaria \\
\hline Graham-Little syndrome & & $\begin{array}{l}\text { Cutaneous adverse drug reaction (including } \\
\text { Stevens-Johnson-syndrome/toxic epidermal } \\
\text { necrolysis) }\end{array}$ \\
\hline Central centrifugal cicatricial alopecia & & Erythromelalgia \\
\hline Chronic telogen effluvium & & Lichen planopilaris \\
\hline Trichotillomania & & Polymorphous light eruption \\
\hline Fox-Fordyce disease & & Actinic prurigo \\
\hline Rosacea fulminans & & Prurigo pigmentosa \\
\hline Acne excoriée & & Granuloma annulare \\
\hline Lichen nuchae & & Necrobiosis lipoidica \\
\hline Perioral dermatitis & & Sarcoidosis \\
\hline Melasma & & Erythema nodosum \\
\hline Hori nevus & & Partial lipodystrophy \\
\hline Dercum's disease & & Ota nevus \\
\hline Angioma serpiginosum & & Adult tinea capitis \\
\hline Hidradenoma papilliferum & & Trichilemmal cyst/proliferating trichilemmal cyst \\
\hline Erosive adenomatosis of nipple & & Pilomatricoma \\
\hline Multiple dermatofibroma & & Cylindroma \\
\hline \multirow[t]{6}{*}{ Mammary Paget's disease } & & Eruptive syringoma \\
\hline & & Subungual glomus tumour \\
\hline & & Angiokeratoma of Mibelli \\
\hline & & Subcutaneous panniculitis-like T-cell lymphoma \\
\hline & & Primary cutaneous large B-cell lymphoma, leg type \\
\hline & & Lentigo maligna \\
\hline
\end{tabular}

Table 2 Skin diseases with significant male predominance (except male genital diseases)

\begin{tabular}{|c|c|c|}
\hline High (male/female ratio $\geq 9$ ) & Moderate (male/female ratio 5-8) & Low (male/female ratio 2-4) \\
\hline Male pattem baldness & Kimura disease & Infantile acne \\
\hline Acne fulminans & Papuloerythroderma of Ofuji & Eosinophilic pustular folliculitis (Ofuji disease) \\
\hline $\begin{array}{l}\text { Perifolliculitis capitis abscedens et } \\
\text { suffodiens }\end{array}$ & $\begin{array}{l}\text { Kaposi sarcoma (iatrogenic and } \\
\text { AIDS-associated) }\end{array}$ & Thromboangiitis obliterans (Buerger disease) \\
\hline Juvenile xanthogranuloma & & Cutaneous angiosarcoma of the scalp and face \\
\hline Juvenile spring eruption of the ears & & Folliculitis decalvans \\
\hline Acne keloidalis nuchae & & Chronic actinic dermatitis (actinic reticuloid) \\
\hline Rhinophyma & & Subcutaneous and systemic mycoses \\
\hline Anglokeratoma scrotl (Fordyce) & & Langerhans cell histlocytosis \\
\hline Madelung disease & & Cutaneous T-cell lymphoma \\
\hline \multirow[t]{3}{*}{ Kaposi sarcoma (classic and endemic) } & & Primary cutaneous marginal zone lymphomas \\
\hline & & Primary cutaneous follicle centre lymphoma \\
\hline & & Melanoma of the trunk \\
\hline
\end{tabular}

fulminans) $)^{3,19}$ or in senescence (e.g. papuloerythroderma of Ofuji, actinic reticuloid, angiosarcoma of the scalp and face of the elderly and Merkel cell carcinoma). ${ }^{3,22,77,78}$ Moreover, there are some spe- cial clinical patterns regarding gender differences in skin diseases: (i) The disease activity may begin near puberty and is full-blown in reproductive age but then subside after menopause. For 
example, systemic lupus erythematosus (LE) exhibits a femaleto-male ratio of $3: 1$ before puberty, 10-15:1 during the reproductive years, and $8: 1$ after menopause. ${ }^{98}$ (ii) There is no gender difference or even male preference before puberty, but females predominate afterwards and accentuate further in senile ages. Tinea capitis is more common in boys of school-age and adolescent ages but affects 3-4 folds more adult women than men, especially after menopause. ${ }^{36,37}$ Trichotillomania affects slightly more boys in pre-school ages, but more girls in adolescent ages, and show distinct female preponderance in adult ages $(4: 1)$ and most extreme in the oldest group (15: 1). ${ }^{99}$ Atopic eczema in pre-school children shows insignificant gender difference or slightly male preponderance in different studies, with significantly more adult females suffering from atopic eczema. ${ }^{27,28}$ (iii) Gender differences can alternate at different ages for the same disease. For instance, infantile acne is predominantly seen in boys, ${ }^{16,18}$ while acne excoriée and acne of late onset are mostly seen in women. ${ }^{3,100}$ (iv) The disease prevalence may not differ much but the disease severity is pronounced in men, e.g. androgenetic alopecia. ${ }^{53}$ (v) Sexual dimorphism differs in various geographical areas and under ethnic backgrounds (see later). (vi) Gender preference may differ among the different types of the same dermatoses. Angiokeratoma of Fordyce involves mainly males but angiokeratoma of Mibelli is predominantly seen in young girls. ${ }^{64}$ Multiple cutaneous lipomas (lipomatosis) such as Dercum's disease occur predominantly in women while benign symmetric lipomatosis (Madelung disease) occur mainly in men..$^{92,93}$ Cutaneous T-cell lymphomas generally affect more men than women, ${ }^{79}$ especially follicular mycosis fungoides and Sezary syndrome, ${ }^{80,81}$ with the exception of subcutaneous panniculitis-like T-cell lymphoma, in which females outnumber males. ${ }^{82}$ In the new WHO-EORTC classification of cutaneous lymphomas, primary cutaneous marginal zone lymphomas and primary cutaneous follicle centre lymphoma occur more commonly in males, while primary cutaneous large B-cell lymphoma, leg type affects more women. ${ }^{83,84}$ (vii) Gender effect has been also observed in disease prognosis. In primary cutaneous melanoma, increasing age and male gender are independently associated with thicker tumours ( $>2 \mathrm{~mm}$ ) and histological ulceration. ${ }^{85}$ Rapid tumour growth has been observed more frequently in males, especially in those above the age of 70 years. ${ }^{86}$ Melanoma of the trunk showed a striking male predilection, especially in the old age group, ${ }^{87}$ while lentigo maligna and acral lentiginous melanoma involve more females than males. ${ }^{8-90}$ Worldwide, female melanoma patients have superior survival compared with males, ${ }^{91}$ but this difference seems to disappear after the age of 65 years. $^{85}$ Younger melanoma patients have a more favourable prognosis than older patients, a difference being more pronounced in women. ${ }^{85}$

The aetiology and pathogenesis in causing gender differences in the development of skin disorders remain incompletely understood. To be considered are gender differences in the structure and function of the skin, hormonal influence, genetic predisposi- tion, sociocultural background and geographical/environmental factors.

\section{Gender differences in the structure and function of the skin}

The thickness and mass of stratum corneum appear to be genderindependent in most studies. ${ }^{101-103}$ No difference exists between men and women regarding the hydration and adhesion of stratum corneum. There are conflicting results about the gender difference in the values of trans-epidermal water loss (TEWL).

Studies on gender differences in skin surface $\mathrm{pH}$ show controversial results in different body regions, partly because of the lack of standardized methodology. ${ }^{103}$ In a recent Korean study, men, as compared with women, exhibit significantly higher sebum casual levels but lower $\mathrm{pH}$ values on the facial sites. ${ }^{104}$ Another recent French study shows no significant gender differences in sebum secretion rate, TEWL and stratum corneum hydration, but a higher skin $\mathrm{pH}$ value in the flexural side of forearm in women. ${ }^{105}$ Although a higher incidence of irritant contact dermatitis has been reported in women than in men, the skin irritability as measured in experimental studies does not show gender preference.

Measurement of dermal thickness and collagen volume/density shows higher values in men than in women, while men demonstrate a gradual thinning with advancing age (12-93 years) but women have a constant skin thickness up to fifth decade, after which it decreases with age. ${ }^{101,103}$ The skin elasticity, torsional extensibility and cutaneous extensibility do not differ between sexes, but it takes longer periods to induce artificially the suction blisters in women. Subcutaneous fat remains identical in thickness before puberty but thenceforth increases significantly more in women with elevated activity of lipoprotein lipase.

There are no functional differences between men and women in the cutaneous microvascular response to histamine. However, the sweating response to heat load appears to be lower in women than in men, ${ }^{106}$ and females demonstrate a higher threshold in the onset of post-exercise sweating. ${ }^{107}$ Qualitatively, gender-specific volatile compounds have been identified in the axillary sweat. ${ }^{108}$ Women are more sensitive to small temperature changes and to pain induced by heat, cold or prick. Women tend to report greater pain sensitivity and severity, which, in addition to sociocultural factors, can also be explained by the gender-based difference in pain perception and central processing of pain. ${ }^{109,110}$ On the other hand, women display greater pain tolerance than men on both behavioural and physiological levels. ${ }^{11}$ Significant gender differences have been found in pruritogen-induced scratching behaviour in mice, with higher scratching scores in females. ${ }^{112}$ The possibility of gender differences in the prevalence and severity of itch in humans deserves further attention.

The anatomical and physiological distinction between female and male genitalia predisposes to different dermatoses; Zoon's 
plasma cell balanitis and erythroplasia of Queyrat are mostly observed in men with redundant prepuce, while pregnancy dermatoses occur exclusively in women. However, it remains largely unknown why lichen sclerosus et atrophicus, erosive adenomatosis of nipple, ${ }^{113}$ eruptive syringoma, ${ }^{63,114}$ hidradenoma papilliferum involve mostly female instead of male genitalia.

In vitro oestradiol has been demonstrated to directly induce melanogenesis ${ }^{15}$ and to increase the expression of human melanocortin 1 receptor, ${ }^{116}$ which may be partly responsible for the female predisposition to pigmentary dermatoses.

\section{Cender differences in immune responses}

In some experimental models, specific immune responses have been found to be more intense in females than in males. ${ }^{117}$ Expression of both oestrogen and androgen receptors have been demonstrated on leucocytes and inflammatory cells such as dendritic cells, ${ }^{118}$ macrophages, lymphocytes, ${ }^{119}$ neutrophils, ${ }^{120}$ and mast cells. ${ }^{121}$ Membrane-bound androgen receptors and membrane-bound oestrogen receptors, which mediate rapid nongenomic effects, have been identified in many immune cells. ${ }^{122}$ Physiological concentration of $\mathrm{E} 2$ can affect the differentiation and maturation of dendritic cells including epidermal Langerhans cells. ${ }^{123,124}$ Antigen-presenting cells from females are more effcient in presenting peptides than those from males, and the phagocytic activity of neutrophils and macrophages is higher in females than in males. ${ }^{125}$ On the other hand, E2 pre-treatment suppresses the antiviral response in dendritic cells. ${ }^{126}$ In humans and mice, E2 at periovulatory to pregnancy levels stimulates interleukin (IL)-4, IL-10, and interferon- $\gamma$ but inhibits tumour necrosis factor- $\alpha$ (TNF- $\alpha$ ) from CD4 + T cells, leading to an overall effect of down-regulation of T-cell-mediated immunity. ${ }^{127}$ Serum levels of E2 in adult women can also enhance antibody secretion but induce suppression of bone marrow B-cell lineage precursors. ${ }^{128}$ In anti-DNA antibody transgenic mice, elevated levels of oestrogen or prolactin can promote the survival and activation of highaffinity autoreactive B cells. ${ }^{128}$ Physiological concentrations of E2, alone or in combination with environmental oestrogens such as organochloride pesticides and polychlorinated biphenyls are able to cause a rapid non-genomic, ER- $\alpha$-mediated IgE-dependent release of $\beta$-hexosaminidase and leucotriene $\mathrm{C} 4$ from mast cells. ${ }^{121,129}$

The influence of androgens on immune responses is less clearly defined. Androgens tend to exert rather immunosuppressive effects by: (i) limiting lymphocyte proliferation and reducing immunoglobulin production; (ii) inhibiting the synthesis of proinflammatory products like TNF- $\alpha$ and nitric oxide synthase; (iii) suppressing the synthesis of pro-inflammatory transcriptional regulators such as NF-kB and $\mathrm{p} 38$ MAP kinase; (iv) increasing the synthesis of anti-inflammatory cytokines such as $\Pi-10 ;{ }^{130}$ and (v) reducing the leucotriene biosynthesis in stimulated whole blood or neutrophils from males. ${ }^{130}$ The UV doses required for immunosuppression are three times lower in men in an experimental model. ${ }^{131}$

\section{Gender differences in genetics and molecular biology}

Recent studies suggest that sex-specific genetic architecture also influences human phenotypes, including reproductive, physiologi$\mathrm{cal}$ and disease traits. The underlying mechanism may be caused by sex-biassed gene expression, sex-specific alternative pre-mRNA splicing, ${ }^{132}$ sex-specific gene-environment interactions, and sex-specific changes in gene regulation with age, particularly in sex steroid-responsive genes. ${ }^{133}$ In a mouse study on UVB-induced skin carcinogenesis, tumours in male mice developed earlier and tended to be larger in size with greater total tumour burden and advanced histological grade than in female mice. The tumour formation was more influenced by the extent of oxidative DNA damage and antioxidant capacities than by inflammatory response. ${ }^{134}$

Both the mitochondrial genome and the $\mathrm{X}$ chromosome are asymmetrically inherited in Drosophila and mammals. Age-related mitochondrial oxidative stress is highly gender dependent. ${ }^{135}$ On the basis of the mitochondrial theory of ageing, mitochondria from female rats generate half the amount of hydrogen peroxide than those of males and have higher levels of mitochondrial reduced glutathione, while the oxidative damage of mitochondrial DNA is fourfold higher in males than in females. Higher levels of oestrogens in females can up-regulate the expression of longevityrelated antioxidant genes, such as those of selenium-dependent glutathione peroxidase and $\mathrm{Mn}$-superoxide dismutase to protect against ageing process. ${ }^{136}$ The female benefit is also associated with polymorphism of $\mathrm{X}$-linked genes and cellular mosaicism for $\mathrm{X}$-linked parental alleles, which confers a more adaptive and balanced cellular machinery that is advantageous in the host response to injury and infection. Several genes encoding key metabolic and regulatory proteins reside on the $\mathrm{X}$ chromosome, including members of the apoptotic cascade, hormone homeostasis, glucose metabolic enzymes, superoxide-producing machinery, and the toll-like receptor/nuclear factor kappaB/c-Jun $\mathrm{N}$-terminal kinase signalling pathway. ${ }^{137}$ The fact of female longevity may also influence the gender prevalence in disease formation.

\section{Gender differences in sociocultural backgrounds}

Higher awareness and self-report may be one of the reasons to explain the much higher incidence of chronic telogen effluvium and loose anagen hair syndrome in female patients. ${ }^{45,46}$ Allergic contact hypersensitivity to nickel, cobalt and cosmetics is obviously more common in females, ${ }^{138,139}$ most likely due to a repeated contact history. Female preponderance is also seen in hand eczema, especially in the form of irritant contact dermatitis, while men exhibit more commonly the form of allergic contact dermatitis. ${ }^{140}$ Traumatic hairstyling techniques are popular in African-American women, frequently leading to scarring alopecia. ${ }^{141}$

On the other hand, male predominance in skin and systemic infections is usually explained by the frequent outdoor activities and the higher exposure risk, such as systemic histoplasmosis, 
blastomycosis and most strikingly paracoccidioidomycosis as well as subcutaneous mycoses such as chromoblastomycosis, sporotrichosis and mycetoma. ${ }^{142-147}$ A significantly higher male-to-female ratio is found in the opportunistic systemic infection of cryptococcosis and pneumocystis carinii. ${ }^{41}$ Men are more susceptible than women to invasive fungal infections after renal transplantation. ${ }^{42}$ Gender difference in sporotrichosis, however, is region-dependent, in which more female cases are reported from Japan and India, probably because of the frequent involvement of women in the farming. ${ }^{148}$ In addition to the exposure factor, there is experimental evidence indicating the protective role of oestrogen in inhibiting the transition of conidia-mycelial propagules to the yeast form, a critical step in the pathogenesis of the disease. ${ }^{149}$

However, among the infectious diseases, it remains unclear why Verruca planae juveniles occurs five times more frequently in females than in males, ${ }^{35}$ but tinea capitis is more common in boys of school-age and adolescent ages but affects three- to fourfold more adult women than men, especially after menopause. ${ }^{36,37}$ Males generally predominate in leprosy, including rare variants such as histoid leprosy, ${ }^{38}$ in which multibacillary leprosy predominates in males while paucibacillary leprosy predominates in females. ${ }^{39}$

\section{Cender differences in geographical aspects}

Geographical differences in disease prevalence have been observed in extra mammary Paget's disease, in which females are mainly affected in Western countries but studies in Asian people display a male-predominant manifestation; ${ }^{150,151}$ Winiwarter-Buerger disease (thromboangiitis obliterans) affects mostly young, male, heavy tobacco smokers of Indo-Asian descent. ${ }^{57,58}$ Most cases of Hori naevus, Ota naevus, Kimura disease and prurigo pigmentosa have been reported from Asian countries, whereas acne fulminans, hidradenitis suppurativa, chronic actinic dermatitis, polymorphous light eruption and actinic prurigo seem to more commonly observed in Western populations. Central centrifugal cicatricial alopecia has so far been reported mostly in African-American women, ${ }^{152}$ while acne keloidalis nuchae is commonly seen in African males. The female predisposition to chronic venous insufficiency/varicose vein/ulcus cruris venosum is less obvious in Asian people than in Western population and varies widely in Western countries according to different studies. ${ }^{54-56}$ It is conceivable that geographical differences are partly affected by genetics, environmental factors, and the sociocultural differences in attitudes of doctor access and availability of medical care.

\section{Conclusions}

Oestrogens appear to affect mainly collagen synthesis, adipose tissues and cutaneous vessels while androgens influence more the function of hair follicles, sebaceous glands and eccrine/apocrine sweat glands. In addition to the hormonal effect that may be considered as 'initiator', the external environmental factors seem to act as 'promoter' to accelerate and enhance the disease develop- ment, such as ultraviolet irradiation in LE and melasma, smoking in acne inversa ${ }^{153-155}$ and Buerger disease, ${ }^{156}$ and irritants in perioral dermatitis. Psychosocial stress should also play a key role in the development of acne excoriée and trichotillomania. Increasing experimental data suggest an influence of oestrogens on the activation of immune responses, while more work is needed to clarify the role of androgens. Population-based studies are warranted to confirm the gender differences identified in hospital-based observations. Ethnic background should be considered in the analysis of the role of sex dimorphism in disease pathogenesis. Further observation is worthwhile to see whether behaviour change will modify disease occurrence, e.g. whether higher prevalence of smoking will lead to increased incidence of thromboangitis obliterans in women. ${ }^{156}$

We are in an era of fast expanding awareness of the fundamental biological and sociocultural differences between men and women that affect health and development of physical or mental diseases. The impact of gender differences on the development and manifestation of disease is multidimensional, influenced by the interplay between genetic predisposition, hormonal regulation, environmental factors and sociocultural background. The goal is to advance the understanding of basic biology and thus elucidate the mechanisms through which sex or gender differences operate in humans in health and disease. On this basis, new preventive, diagnostic, and therapeutic concepts may be developed.

\section{References}

1 Gruber CJ, Tschugguel W, Schneeberger C, Huber JC. Production and actions of estrogens. $N$ Engl J Med 2002; 346: 340-352.

2 Federman DD. The biology of human sex differences. $N$ Engl J Med 2006; 354: 1507-1514.

3 Burns T, Breathnach S, Cox N, Griffiths C (eds) Rook's Textbook of Dermatology. Wiley-Blackwell, Oxford, 2006.

4 Dao H Jr, Kazin RA. Gender differences in skin: a review of the literature. Gend Med 2007; 4: 308-328.

5 Schuna AA. Autoimmune rheumatic diseases in women. J Am Pharm Assoc (Wash) 2002; 42: 612-623.

$6 \mathrm{Yu}$ CY, Whitacre CC. Sex, MHC and complement C4 in autoimmune diseases. Trends Immunol 2004; 25: 694-699.

7 Plewig G, Jansen T, Kligman AM. Pyoderma faciale. A review and report of 20 additional cases: is it rosacea?. Arch Dermatol 1992; 128: 1611-1617.

8 Wilkinson DS, Kirton V, Wilkinson JD. Perioral dermatitis: a 12-year review. Br J Dermatol 1979; 101: 245-257.

9 Davis MD, O'Fallon WM, Rogers RS III, Rooke TW. Natural history of erythromelalgia. Arch Dermatol 2000; 136: 330-336.

10 Böer A, Misago N, Wolter M et al. Prurigo pigmentosa: a distinctive inflammatory disease of the skin. Am J Dermatopathol 2003; 25: 117129.

11 Baykal C, Buyukbabani N, Akinturk S, Saglik E. Prurigo pigmentosa: not an uncommon disease in the Turkish population. Int J Dermatol 2006; 45: 1164-1168.

12 Revuz JE, Canoui-Poitrine F, Wolkenstein P et al. Prevalence and factors associated with hidradenitis suppurativa: results from two case-control studies. J Am Acad Dermatol 2008; 59: 596-601.

13 Dabski K, Winkelmann RK. Generalized granuloma annulare: clinical and laboratory findings in 100 patients. I Am Acad Dermatol 1989; 20: 39-47. 
14 Peyrí J, Moreno A, Marcoval J. Necrobiosis lipoidica. Semin Cutan Med Surg 2007; 26: 87-89.

15 Stein JA, Fangman B, Strober B. Actinic granuloma. Dermatol Online J 2007; 13: 19.

16 English JC III, Patel PJ, Greer KE. Sarcoidosis. J Am Acad Dermatol 2001; 44: 725-743.

17 Cunliffe WJ, Baron SE, Coulson IH. A clinical and therapeutic study of 29 patients with infantile acne. Br J Dermatol 2001; 145: 463-466.

18 Hello M, Prey S, Léauté-Labrèze C et al. Infantile acne: a retrospective study of 16 cases. Pediatr Dermatol 2008; 25: 434-438.

19 Jansen T, Plewig G. Acne fulminans. Int J Dermatol 1998; 37: 254257.

20 Furukawa M, Kanetou K, Hamada T. Rhinophyma in Japan. Int J Der matol 1994; 33: 35-37.

21 Rohrich RJ, Griffin JR, Adams WP Jr. Rhinophyma: review and update. Plast Reconstr Surg 2002; 110: 860-869.

22 Lim HW, Morison WL, Kamide $\mathrm{R}$ et al. Chronic actinic dermatitis: an analysis of 51 patients in the United States and Japan. Arch Dermatol 1994; 130: 1284-1289.

23 Bork K, Barnstedt SE, Koch P, Traupe H. Hereditary angioedema with normal C1-inhibitor activity in women. Lancet 2000; 356: 213-217.

24 Webb JA, Stacul F, Thomsen HS, Morcos SK. Members Of The Con trast Media Safety Committee Of The European Society Of Urogenital Radiology. Late adverse reactions to intravascular iodinated contrast media. Eur Radiol 2003; 13: 181-184.

25 Nakada $T$, Akiyama $M$, Iijima $M$ et al. Drug eruptions to contrast media in Japan. Clin Fxp Dermatol 2006; 31: 361-364.

26 Kasperska-Zajac A, Brzoza Z, Rogala B. Sex hormones and urticaria. J Dermatol Sci 2008; 52: 79-86.

27 Chen W, Mempel M, Schober W et al. Gender difference, sex hormones, and immediate type hypersensitivity reactions. Allergy 2008; 63: 1418-1427.

28 Möhrenschlager M, Schäfer T, Huss-Marp J et al. The course of eczema in children aged 5-7 years and its relation to atopy: differences between boys and girls. Br I Dermatol 2006; 154: 505-513.

29 Gomes ER, Demoly P. Epidemiology of hypersensitivity drug reactions. Curr Opin Allergy Clin Immunol 2005; 5: 309-316.

30 Bigby M. Rates of cutaneous reactions to drugs. Arch Dermatol 2001; 137: 765-770.

31 French LE. Toxic epidermal necrolysis and Stevens Johnson syndrome: our current understanding. Allergol Int 2006; 55: 9-16.

32 Gerdts B, Vloemans AF, Kreis RW. Toxic epidermal necrolysis: 15 years' experience in a Dutch burns centre. I Eur Acad Dermatol Venereol 2007; 21: 781-788.

33 Halevy S, Ghislain PD, Mockenhaupt $M$ et al Allopurinol is the most common cause of Stevens-Johnson syndrome and toxic epidermal necrolysis in Europe and Israel. J Am Acad Dermatol 2008; 58: 25-32.

34 Auquier-Dunant A, Mockenhaupt M, Naldi L et al. Correlations between clinical patterns and causes of erythema multiforme majus, Stevens-Johnson syndrome, and toxic epidermal necrolysis: results of an international prospective study. Arch Dermatol 2002; 138: 1019 1024 .

35 Kilkenny M, Merlin K, Young R, Marks R. The prevalence of common skin conditions in Australian school students: 1. Common, plane and plantar viral warts. Br J Dermatol 1998; 138: 840-845.

36 Lee IY, Hsu ML. Tinea capitis in adults in southern Taiwan. Int J Dermatol 1991; 30: 572-575.

37 Prohic A. An epidemiological survey of tinea capitis in Sarajevo, Bosnia and Herzegovina over a 10-year period. Mycoses 2008; 51: 161164.

38 Kaur I, Dogra S, De D, Saikia UN. Histoid leprosy: a retrospective study of 40 cases from India. Br J Dermatol 2009; 160: 305-310.

39 Vargas-Ocampo F. Analysis of 6000 skin biopsies of the national leprosy control program in Mexico. Int J Lepr Other Mycobact Dis 2004; 72: $427-436$.
40 Ivanov OL, Lvov AN, Michenko AV et al. Autoerythrocyte sensitization syndrome (Gardner-Diamond syndrome): review of the literature. J Eur Acad Dermatol Venereol 2009; 23: 499-504.

41 Lamagni TL, Evans BG, Shigematsu M, Johnson EM. Emerging trends in the epidemiology of invasive mycoses in England and Wales (19901999). Epidemiol Infect 2001; 126: 397-414.

42 Einollahi $B$, Lessan-Pezeshki $M$, Pourfarziani $V$ et al. Invasive fungal infections following renal transplantation: a review of 2410 recipients. Ann Transplant 2008; 13: 55-58.

43 Suh DH, Hwang JH, Lee HS et al. Clinical features of Ota's naevus in Koreans and its treatment with Q-switched alexandrite laser. Clin Exp Dermatol 2000; 25: 269-273.

44 Fe HL, Wong HC, Goh CL, Ang P. Characteristics of Hori naevus: a prospective analysis. Br J Dermatol 2006; 154: 50-53.

45 Whiting DA. Chronic telogen effluvium: increased scalp hair shedding in middle aged women. J Am Acad Dermatol 1996; 35: 899-906.

46 Tosti A, Piraccini BM. Loose anagen hair syndrome and loose anagen hair. Arch Dermatol 2002; 138: 521-522.

47 Chieregato C, Zini A, Barba A et al. Lichen planopilaris: report of 30 cases and review of the literature. Int J Dermatol 2003; 42: 342-345.

48 Scheinfeld NS. A case of dissecting cellulitis and a review of the literature. Dermatol Online J 2003; 9: 8.

49 Annessi G. Tufted folliculitis of the scalp: a distinctive clinicohistological variant of folliculitis decalvans. Br J Dermatol 1998; 138: 799-805.

50 Powell JJ, Dawber RP, Gatter K. Folliculitis decalvans including tufted folliculitis: clinical, histological and therapeutic findings. $\mathrm{Br} J$ Dermatol 1999; 140: 328-333.

51 Brooke RC, Griffiths CE. Folliculitis decalvans. Clin Exp Dermatol 2001; 26: 120-122.

52 Chandrawansa PH, Giam YC. Folliculitis decalvans-a retrospective study in a tertiary referred centre, over five years. Singapore Med J 2003; 44: 84-87.

53 Price VH. Androgenetic alopecia in women. I Investig Dermatol Symp Proc 2003; 8: 24-27.

54 Canonico S, Gallo C, Paolisso $\mathrm{G}$ et al. Prevalence of varicose veins in an Italian elderly population. Angiology 1998; 49: 129-135.

55 Boccalon H, Janbon C, Saumet JL et al. Characteristics of chronic venous insufficiency in 895 patients followed in general practice. Int Angiol 1997; 16: 226-234.

56 De Backer G. Epidemiology of chronic venous insufficiency. Angiology 1997; 48: 569-576.

57 Mills Лl Sr. Buerger's disease in the 21st century: diagnosis, clinical features, and therapy. Semin Vasc Surg 2003; 16: 179-189.

58 Makin A, Silverman S, Lip GY. Ethnic differences in peripheral vascular disease. Int J Clin Pract 2002; 56: 605-608.

59 Fimmel S, Zouboulis CC. Influence of physiological androgen levels on wound healing and immune status in men. Aging Male 2005; 8: $166-174$.

60 Kaur C, Sarkar R, Kanwar AJ, Mohan H. Multiple eccrine hidrocystomas. J Eur Acad Dermatol Venereol 2002; 16: 288-290.

61 Satyaprakash AK, Sheehan DJ, Sangüeza OP. Proliferating trichilemmal tumors: a review of the literature. Dermatol Surg 2007; 33: 1102-1108.

62 Price HN, Zaenglein AL. Diagnosis and management of benign lumps and bumps in childhood. Curr Opin Pediatr 2007; 19: 420-424.

63 Soler-Carrillo J, Estrach T, Mascaró JM. Eruptive syringoma: 27 new cases and review of the literature. J Eur Acad Dermatol Venereol 2001; 15: 242-246.

64 Mittal R, Aggarwal A, Srivastava G. Angiokeratoma circumscriptum: a case report and review of the literature. Int J Dermatol 2005; 44: 1031-1034.

65 Zelger $B$, Zelger BG, Burgdorf WH. Dermatofibroma-a critical evalua tion. Int J Surg Pathol 2004; 12: 333-344.

66 Vasisht B, Watson HK, Joseph E, Lionelli GT. Digital glomus tumors: a 29-year experience with a lateral subperiosteal approach. Plast Recon str Surg 2004; 114: 1486-1489. 
67 McDermott EM, Weiss AP. Glomus tumors. J Hand Surg [Am] 2006; 31: $1397-1400$.

$68 \mathrm{Wu}$ KK. Morton neuroma and metatarsalgia. Curr Opin Rheumatol 2000; 12: 131-142.

69 Toro JR, Nickerson ML, Wei MH et al. Mutations in the fumarate hydratase gene cause hereditary leiomyomatosis and renal cell cancer in families in North America. Am I Hum Genet 2003; 73: 95-106.

70 Bayley JP, Launonen V, Tomlinson IP. The FH mutation database: an online database of fumarate hydratase mutations involved in the MCUL (HLRCC) tumor syndrome and congenital fumarase deficiency. BMC Med Genet 2008; 9: 20.

71 Launonen V, Vierimaa $\mathrm{O}$, Kiuru $\mathrm{M}$ et al. Inherited susceptibility to uterine leiomyomas and renal cell cancer. Proc Natl Acad Sci USA 2001; 98: 3387-3392.

72 Grubb RL III, Franks ME, Toro J et al. Hereditary leiomyomatosis and renal cell cancer: a syndrome associated with an aggressive form of inherited renal cancer. J Urol 2007; 177: 2074-2079.

73 Salotti JA, Nanduri V, Pearce MS, Parker L, Lynn RM, Windebank KP. Incidence and clinical features of langerhans cell histiocytosis in the UK and Ireland. Arch Dis Child 2009; 94: 376-380.

74 Yağci B, Varan A, Cağlar $M$ et al. Langerhans cell histiocytosis: retrospective analysis of 217 cases in a single center. Pediatr Hematol Oncol 2008; 25: 399-408.

75 Guyot-Goubin A, Donadieu J, Barkaoui M et al. Descriptive epidemiology of childhood Langerhans cell histiocytosis in France, 2000-2004. Pediatr Blood Cancer 2008; 51: 71-75.

76 Janssen D, Harms D. Juvenile xanthogranuloma in childhond and adolescence: a clinicopathologic study of 129 patients from the Kiel pediatric tumor registry. Am J Surg Pathol 2005; 29: 21-28.

77 Morgan MB, Swann M, Somach S et al. Cutaneous angiosarcoma: a case series with prognostic correlation. I Am Acad Dermatol 2004; 50: 867874.

78 Hodgson NC. Merkel cell carcinoma: changing incidence trends. I Surg Oncol 2005; 89: 1-4.

79 Criscione VD, Weinstock MA. Incidence of cutaneous T-cell lymphoma in the United States, 1973-2002. Arch Dermatol 2007; 143: 854-859.

80 Fink-Puches R, Zenahlik P, Bäck B et al. Primary cutaneous lympho mas: applicability of current classification schemes (European Organization for Research and Treatment of Cancer, World Health Organization) based on clinicopathologic features observed in a large group of patients. Blood 2002; 99: 800-805.

81 van Doorn R, Scheffer E, Willemze R. Follicular mycosis fungoides, distinct disease entity with or without associated follicular mucinosis: a clinicopathologic and follow-up study of 51 patients. Arch Dermatol 2002; 138: 191-198.

82 Willemze R, Jansen PM, Cerroni $L$ et al. Subcutaneous panniculitislike T-cell lymphoma: definition, classification, and prognostic factors: an EORTC Cutaneous Lymphoma Group Study of 83 cases. Blood 2008; 111: 838-845.

83 Grange F, Beylot-Barry M, Courville P et al. Primary cutaneous diffuse large B-cell lymphoma, leg type: clinicopathologic features and prog nostic analysis in 60 cases. Arch Dermatol 2007; 143: 1144-1150.

84 Senff NJ, Hoefnagel JJ, Jansen PM et ah. Reclassification of 300 primary cutaneous B-cell lymphomas according to the new WHOEORTC classification for cutaneous lymphomas: comparison with previous classifications and identification of prognostic markers. J Clin Oncol 2007; 25: 1581-1587.

85 Lasithiotakis $\mathrm{K}_{1}$ Leiter $\mathrm{U}$, Meier $\mathrm{F}$ et al. Age and gender are significant independent predictors of survival in primary cutaneous melanoma. Cancer 2008; 112: 1795-1804.

86 Liu W, Dowling JP, Murray WK et al. Rate of growth in melanomas: characteristics and associations of rapidly growing melanomas. Arch Dermatol 2006; 142: 1551-1558.
87 Pérez-Gómez. B, Aragonés N, Gustavsson P et al. Do sex and site matter? Different age distribution in melanoma of the trunk among Swedish men and women $B r J$ Dermatol 2008; 158: 766-772.

88 Al-Niaimi F, Jury CS, McLaughlin S, Herd RM. Review of management and outcome in 65 patients with lentigo maligna. $\mathrm{Br} J$ Dermatol 2009; 160: 211-213.

89 Kuchelmeister C, Schaumburg-Lever G, Garbe C. Acral cutaneous melanoma in caucasians: clinical features, histopathology and prognosis in 112 patients. Br J Dermatol 2000; 143: 275-280.

90 Phan A, Touzet S, Dalle $S$ et al. Acral lentiginous melanoma: a clinicoprognostic study of 126 cases. Br J Dermatol 2006; 155: 561-569.

91 de Vries E, Nijsten TE, Visser $O$ et al. Superior survival of females among 10,538 Dutch melanoma patients is independent of Breslow thickness, histologic type and tumor site. Ann Oncol 2008; 19: 583589.

92 Moraru RA. Lipomas. [WWW document] 2008. URL http://emedicine medscape.com/article/1057855-overview (last accessed: 26 December 2008).

93 Lee HW, Kim TH, Cho JW et al. Multiple symmetric lipomatosis: Korean experience. Dermatol Surg 2003; 29: 235-240.

94 Mbulaiteye SM, Engels EA. Kaposi's sarcoma risk among transplant recipients in the United States (1993-2003). Int J Cancer 2006; 119: 2685-2691.

95 Meditz AL, Borok M, MaWhinney S et al. Gender differences in AIDS-associated Kaposi sarcoma in Harare, Zimbabwe. J Acquir Immune Defic Syndr 2007; 44: 306-308.

96 Plancoulaine S, Abel L, van Beveren M, Gessain A. High titers of antihuman herpesvirus 8 antibodies in elderly males in an endemic population. I Natl Cancer Inst 2002; 94: 1333-1335.

97 Dupuy A, Schulz T, Chevret $\mathrm{S}$ et al. Asymmetrical transmission of human herpesvirus 8 among spouses of patients with Kaposi sarcoma. Br J Dermatol 2009; 160: 540-545.

98 Tirumani A, Leber M]. Systemic lupus erythematosus [WWW document] 2008. URL http://emedicine.medscape.com/article/809378overview (last accessed: 26 December 2008).

99 Millard LG, Cotterill JA. Trichotillomania Psychocutaneous disorders. In Burns T, Breathnach S, Cox N, Griffiths C, eds. Rook's Textbook of Dermatology, 7th edn. Blackwell Science Ltd, Oxford, UK, 2004: 61.21-61.23.

$100 \mathrm{Yu}$ YS, Cheng YW, Chen W. Lifetime course of acne: a retrospective questionnaire study in school teachers. Dermatol Sinica 2008; 26: 10-15.

101 Tur E. Physiology of the skin-differences between women and men Clin Dermatol 1997; 15: 5-16.

102 Jacobi U, Gautier J, Sterry W, Lademann J. Gender-related differences in the physiology of the stratum corneum. Dermatology 2005; 211: 312317.

103 Giacomoni PU, Mammone T, Teri M. Gender-linked differences in human skin. J Dermatol Sci 2009; 55: 144-149.

104 Kim MK, Patel RA, Shinn AH et al. Evaluation of gender difference in skin type and pH. J Dermatol Sci 2006; 41: 153-156.

105 Burry JS, Coulson HF, Esser I et al. Erroneous gender differences in axillary skin surface/sweat pH. Int J Cosmet Sci 2001; 23: 99-107.

106 Kaciuba-Uscilko H, Grucza R. Gender differences in thermoregulation. Curr Opin Clin Nutr Metab Care 2001; 4: 533-536.

107 Kenny GP, Jay O. Evidence of a greater onset threshold for sweating in females following intense exercise. Eur J Appl Physiol 2007; 101: 487493.

108 Penn DJ, Oberzaucher E, Grammer $\mathrm{K}$ et al. Individual and gender fingerprints in human body odour. J R Soc Interface 2007; 4: 331340 .

109 Gazerani P, Wang K, Cairns BE et al. Effects of subcutaneous administration of glutamate on pain, sensitization and vasomotor responses in healthy men and women. Pain 2006; 124: 338-348. 
110 Henderson LA, Gandevia SC, Macefield VG. Gender differences in brain activity evoked by muscle and cutaneous pain: a retrospective study of single-trial fMRI data. Neuroimage 2008; 39: 1867-1876.

111 Garofalo JP, Lawler C, Robinson $\mathrm{R}$ et ah The role of mood states underlying sex differences in the perception and tolerance of pain. Pain Pract 2006; 6: 186-196.

112 Green AD, Young KK, Lehto SG et al. Influence of genotype, dose and sex on pruritogen-induced scratching behavior in the mouse. Pain 2006; 124: 50-58.

113 Bourlond J, Bourlond-Reinert L. Erosive adenomatosis of the nipple. Dermatology 1992; 185: 319-324.

114 Huang YH, Chuang YH, Kuo TT et al. Vulvar syringoma: a clinicopathologic and immunohistologic study of 18 patients and results of treatment. J Am Acad Dermatol 2003; 48: 735-739.

115 Kippenberger $\mathrm{S}$, Loitsch S, Solano $\mathrm{F}$ et al. Quantification of tyrosinase, TRP-1, and Trp-2 transcripts in human melanocytes by reverse transcriptase-competitive multiplex PCR-regulation by steroid hormones. $J$ Invest Dermatol 1998; 110: 364-367.

116 Scott MC, Suzuki I, Abdel-Malek ZA. Regulation of the human melanocortin 1 receptor expression in epidermal melanocytes by paracrine and endocrine factors and by ultraviolet radiation. Pigment Cell Res 2002; 15: 433-439.

117 Verthelyi D. Sex hormones as immunomodulators in health and disease. Int Immunopharmacol 2001; 1: 983-993.

118 Kovats S, Carreras E. Regulation of dendritic cell differentiation and function by estrogen receptor ligands. Cell Immunol 2008; 252: 8190.

119 Marriott I, Huet-Hudson YM. Sexual dimorphism in innate immune responses to infectious organisms. Immunol Res 2006; 34: 177-192.

120 Pergola C, Dodt G, Rossi A et al. ERK-mediated regulation of leukotriene biosynthesis by androgens: a molecular basis for gender differences in inflammation and asthma. Proc Natl Acad Sci USA 2008; 105 : 19881-19886.

121 Narita S, Goldblum RM, Watson CS et al. Environmental estrogens induce mast cell degranulation and enhance $\mathrm{IgE}$-mediated release of allergic mediators. Environ Health Perspect 2007; 115: 48-52.

122 Benten WP, Stephan C, Wunderlich F. B cells express intracellular but not surface receptors for testosterone and estradiol. Steroids 2002; 67: $647-654$.

123 Siracusa MC, Overstreet MG, Housseau F et al. 17beta-estradiol alters the activity of conventional and IFN-producing killer dendritic cells. I Immunol 2008; 180: 1423-1431.

124 Mao A, Paharkova-Vatchkova V, Hardy J et al. Estrogen selectively promotes the differentiation of dendritic cells with characteristics of Langerhans cells. J Immunol 2005; 175: 5146-5151

125 Klein SL. The effects of hormones on sex differences in infection: from genes to behavior. Neurosci Biobehav Rev 2000; 24: 627-638.

126 Escribese MM, Kraus T, Rhee $\mathrm{E}$ et al. Estrogen inhibits dendritic cell maturation to RNA viruses. Blood 2008; 112: 4574-4584.

127 Straub RH. The complex role of estrogens in inflammation. Endocr Rev 2007; 28: 521-574.

128 Grimaldi CM. Sex and systemic lupus erythematosus: the role of the sex hormones estrogen and prolactin on the regulation of autoreactive B cells. Curr Opin Rheumatol 2006; 18: 456-461.

129 Zaitsu M, Narita S, Lambert KC et al. Estradiol activates mast cells via a non-genomic estrogen receptor-alpha and calcium influx. $\mathrm{Mol}$ Immunol 2007; 44: 1977-1985.

130 Choudhry MA, Bland KI, Chaudry IH. Trauma and immune response-effect of gender differences. Injury 2007; 38: 1382-1391.

131 Damian DL, Patterson CR, Stapelberg $M$ et al. UV radiation-induced immunosuppression is greater in men and prevented by topical nico tinamide. J Invest Dermatol 2008; 128: 447-454.

132 Telonis-Scott M, Kopp A, Wayne ML et al. Sex-specific splicing in Drosophila: widespread occurrence, tissue specificity and evolutionary conservation. Genetics 2009; 181: 421-434.
133 Ober C, Loisel DA, Gilad Y. Sex-specific genetic architecture of human disease. Nat Rev Genet 2008; 9: 911-922.

134 Thomas-Ahner JM, Wulff BC, Tober KL et al. Gender differences in UVB-induced skin carcinogenesis, inflammation, and DNA damage. Cancer Res 2007; 67: 3468-3474.

135 Borras C, Gambini J, Vina J. Mitochondrial oxidant generation is involved in determining why females live longer than males. Front Biosci 2007; 12: 1008-1013.

136 Vin̄a J, Sastre J, Pallardó FV, Gambini J, Borrás C. Modulation of longevity-associated genes by estrogens or phytoestrogens. Biol Chem 2008; 389: 273-277.

137 Spolarics $Z$. The $\mathrm{X}$-files of inflammation: cellular mosaicism of $\mathrm{X}$-linked polymorphic genes and the female advantage in the host response to injury and infection. Shock 2007; 27: 597-604.

138 Fors $R$, Persson $M$, Bergström $\mathbf{E}$ et al. Nickel allergy- prevalence in a population of Swedish youths from patch test and questionnaire data. Contact Dermatitis 2008; 58: 80-87.

139 Warshaw EM, Buchholz HJ, Belsito DV et al. Allergic patch test reac tions associated with cosmetics: retrospective analysis of cross-sectional data from the North American Contact Dermatitis Group, 2001-2004. I Am Acad Dermatol 2009; 60: 23-38.

140 Diepgen TL, Andersen KE, Brandao FM et al. Hand eczema classifica tion: a cross-sectional, multicentre study of the aetiology and morphology of hand eczema. Br I Dermatol 2009; 160: 353-358.

141 Borovicka JH, Thomas L, Prince C, Mehregan DR. Scarring alopecia: clinical and pathologic study of 54 African-American women. Int $J$ Dermatol 2009; 48: 840-845.

142 Assi MA, Sandid MS, Baddour LM et al. Systemic histoplasmosis: a 15-year retrospective institutional review of 111 patients. Medicine (Baltimore) 2007; 86: 162-169.

143 Bruce Light R, Kralt D, Embil JM et al. Seasonal variations in the clinical presentation of pulmonary and extrapulmonary blastomycosis. Med Mycol 2008; 46: 835-841.

144 Laniado-Laborín R. Coccidioidomycosis and other endemic mycoses in Mexico. Rev Iberoam Micol 2007; 24: 249-258.

145 Arenas R, Miller D, Campos-Macias P. Epidemiological data and molecular characterization (mtDNA) of Sporothrix schenckii in 13 cases from Mexico. Int J Dermatol 2007; 46: 177-179.

146 Bonifaz A, Carrasco-Gerard E, Saúl A. Chromoblastomycosis: clinical and mycologic experience of 51 cases. Mycoses 2001; 44: 1-7.

147 Zarei Mahmoudabadi A, Zarrin M. Mycetomas in Iran: a review article. Mycopathologia 2008; 165: 135-141.

148 da Rosa AC, Scroferneker ML, Vettorato R et al. Epidemiology of sporotrichosis: a study of 304 cases in Brazil. J Am Acad Dermatol 2005; 52: 451-459.

149 Blotta MH, Mamoni RL, Oliveira SJ et al. Endemic regions of paracoccidioidomycosis in Brazil: a clinical and epidemiologic study of 584 cases in the southeast region. Am J Trop Med Hyg 1999; 61: 390-394.

150 Kanitakis J. Mammary and extramammary Paget's disease. J Eur Acad Dermatol Venereol 2007; 21: 581-590.

151 Yoon SN, Park IJ, Kim HC et al. Extramammary Paget's disease in Korea: its association with gastrointestinal neoplasms. Int J Colorectal Dis 2008; 23: 1125-1130.

152 Whiting DA, Olsen EA. Central centrifugal cicatricial alopecia. Dermatol Ther 2008; 21: 268-278.

153 Happle R, König A. A lesson to be learned from Karl Marx: smoking triggers hidradenitis suppurativa. Br J Dermatol 2008; 159: 255-256.

154 Revuz J. Hidradenitis suppurativa. J Eur Acad Dermatol Venereol 2009; 23: $985-998$.

155 Sartorius K, Emtestam L, Jemec GB, Lapins J. Objective scoring of hidradenitis suppurativa reflecting the role of tobacco smoking and obesity. Br J Dermatol 2009; 161: 831-839.

156 Puéchal X, Fiessinger JN. Thromboangiitis obliterans or Buerger's disease: challenges for the rheumatologist. Rheumatology (Oxford) 2007; 46: $192-199$. 